Jurdimas (Jurnal Pengabdian Kepada Masyarakat)

Vol. I No. 1, Januari 2018, hlm. $34-43$

Available online at

http://jurnal.stmikroyal.ac.id/index.php/jurdimas

\title{
IMPLEMENTASI PERAKITAN DAN INSTALASI SISTEM OPERASI WINDOWS DAN LINUX
}

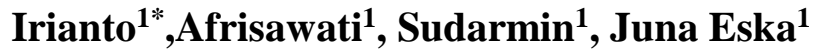 \\ ${ }^{1}$ Program Studi Sistem Informasi, STMIK Royal Kisaran, \\ Email : irianto@royal.ac.id
}

\begin{abstract}
Increased computer users in high school make increasingly also the desire of students / i equal to know the type of computer components. With the many interests of students to know assembling and installation of computers, making their enthusiasm higher in knowing the types of computer applications. Many factors influence for students on computer assembly, such as how component form, type of operating system, type of application, and how to install.
\end{abstract}

Keywords: Computer Components, Operating System, Computer Applications

\begin{abstract}
Abstrak: Peningkatan pengguna komputer di sekolah SMA membuat makin meningkat pula keinginan siswa/i sederajat untuk mengetahui jenis komponen komputer. Dengan banyaknya minat siswa/i untuk mengetahui merakit dan instalasi komputer, membuat antusias mereka semakin tinggi dalam mengetahui jenis aplikasi komputer. Banyak faktor yang mempengaruhi bagi siswa/i pada perakitan komputer, seperti bagaimana bentuk komponen, jenis sistem operasi, jenis aplikasi, dan bagaimana cara instalasinya.
\end{abstract}

Kata Kunci : Komponen Komputer, Sistem Operasi, Aplikasi Komputer

\section{PENDAHULUAN}

Pengabdian kepada masyarakat merupakan pelaksanaan pengalaman ilmu pengetahuan, teknologi dan seni budaya langsung pada masyarakat secara kelembagaan melalui metodologi ilmiah sebagai penyebaran Tri Dharma Perguruan Tinggi serta tanggung jawab yang luhur dalam usaha mengembangkan kemampuan masyarakat, sehingga dapat mempercepat laju pertumbuhan tercapainya tujuan pembanguanan nasional.

Maksud dari kegiatan pengabdian ini adalah melaksanakan Tri Dharma Perguruan Tinggi berupa Pengabdian Kepada Masyarakat sebagai pengamalan ilmu pengetahuan, teknologi khususnya sistem komputer kepada siswa-siswi SMA
Swadaya Tinggi Raja oleh dosen STMIK Royal Kisaran

\section{METODE}

\section{Materi Pengabdian Kepada Masyarakat Materi pengabdian kepada masyarakat disusun sesuai dengan tujuan yang ingin dicapai diantaranya mengenai : mengenal jenis dan hardware-hardware komputer, pemasangan komponen, instalasi system operasi baik windows maupun ubuntu dan workstation (XP dan Windows 7), mengenal sistem operasi, konfigurasi 2 windows, dan lainnya.}


Jurdimas (Jurnal Pengabdian Kepada Masyarakat)

Vol. I No. 1, Januari 2018, hlm. 34 - 43

Available online at

http://jurnal.stmikroyal.ac.id/index.php/jurdimas

\section{Metode Pengabdian Kepada Masyarakat}

Metode pelaksaan dalam pengabdian masyarakat ini adalah dengan cara melaksanakan kegiatan pelatihan dalam bentuk workshop, dengan menjelaskan dasar teori dan praktek langsung.

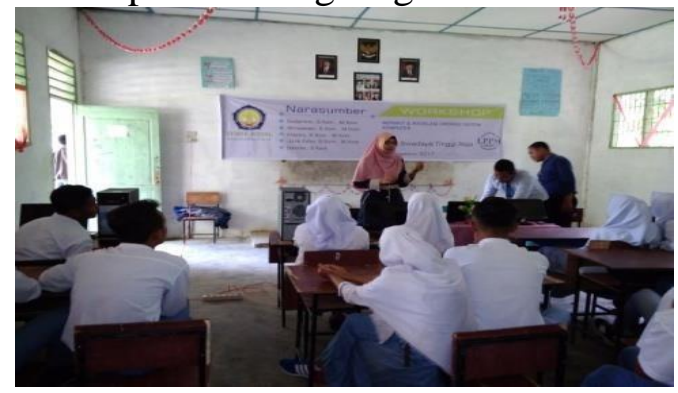

Gambar 6 Mengenalkan Komponen Komputer

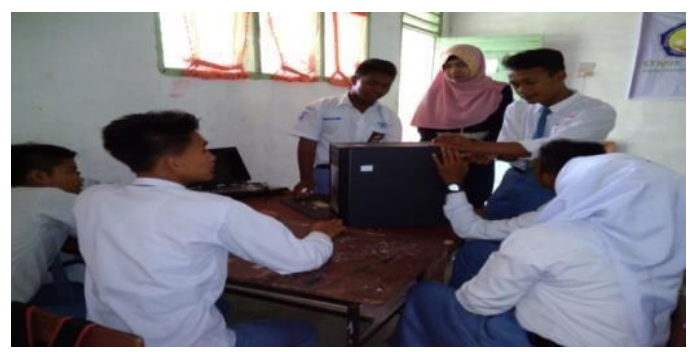

Gambar 7 Memulai Merakit Komponen Komputer

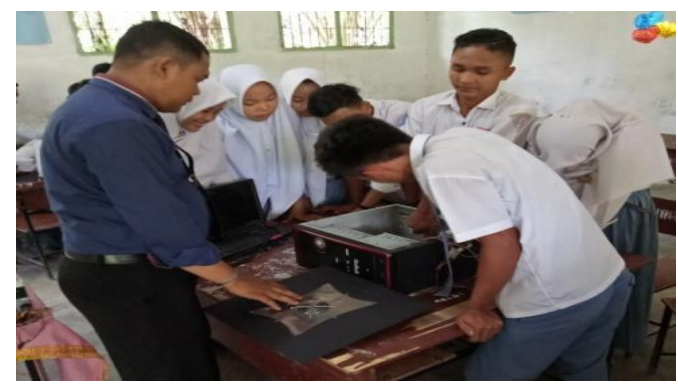

Gambar 8 Siswa/i Secara Langsung Merakit

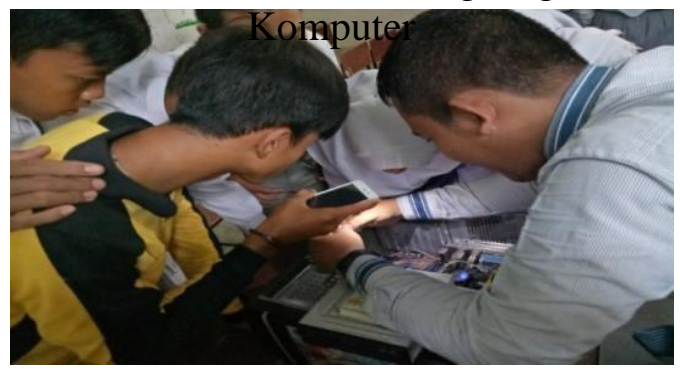

Gambar 9 Intruktur Cek Seluruh Komponen

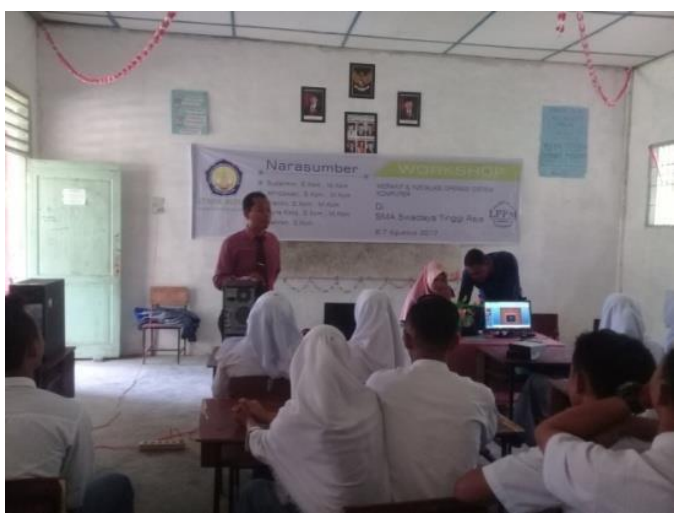

Gambar 10 Memulai Instalasi Komputer

\section{PEMBAHASAN}

\section{Merakit Komputer}

Dalam merakit sebuah komputer ada beberapa tahap yang harus anda lakukan terlebih dahulu. Adapun tahap-tahap tersebut adalah:

\section{Persiapan}

Persiapkan terlebih dahulu komponen-komponen yang diperlukan untuk melakukan perakitan komputer.Lakukan perakitan di tempat yang dimana anda merasa leluasa untuk bergerak sehingga tidak mengganggu aktifitas anda.

\section{Proses Perakitan}

Memulai perakitan komponenkomponen komputer dengan memasang satu persatu hardware yang diperlukan.

\section{Pengujian}

Saat proses perakitan telah terselesaikan, maka tahap selanjutnya adalah pengujian. Pada tahap ini komputer yang selesai dirakit akan dihidupkan dan dioperasikan. Jika pengoperasian berjalan normal maka proses perakitan telah selesai, namun apabila ternyata terjadi masalah maka dilanjutkan pada proses yang selanjutnya, yaitu menangani masalah yang terjadi.

\section{Penanganan Masalah}

Pada tahap ini komputer yang selesai dirakit ternyata mengalami masalah 
Jurdimas (Jurnal Pengabdian Kepada Masyarakat)

Vol. I No. 1, Januari 2018, hlm. 34 - 43

Available online at

http://jurnal.stmikroyal.ac.id/index.php/jurdimas

ISSN 2614-7912 (Print)

ISSN 2622-3813 (Online)

(troubleshoot). Hal tersebut bisa disebabkan oleh proses instalasi atau penempatan komponen yang kurang tepat. Oleh sebab itu diperlukan penanganan lebih lanjut agar komputer bisa beroperasi dengan normal.

\section{Proses Instalasi Operasi Sistem}

Operating System Windows 7 merupakan salah satu dari beberapa produk Microsoft yang pada saat ini lagi booming, paling banyak penggunanya.

Berikut adalah beberapa tahap Cara Install Windows 7

1. Pastikan dari BIOS booting komputer Anda di setting untuk DVD

2. Masukkan DVD windows 7

3. Tekan sembarang tombol saat muncul boot from cd or dvd

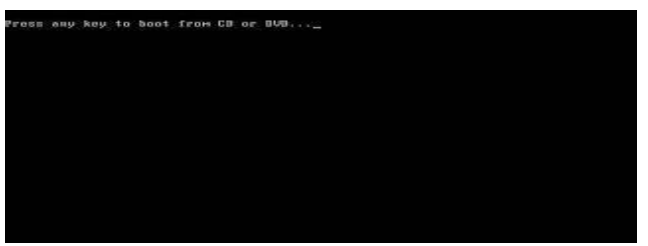

Gambar 11 Bootng CD

4. Akan terlihat gambar seperti dibawah ini

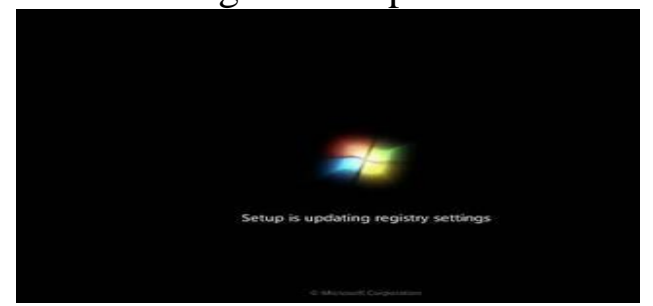

Gambar 12 Loading Windows 7

5. Pilih Indonesian pada Language, time, currency, and location

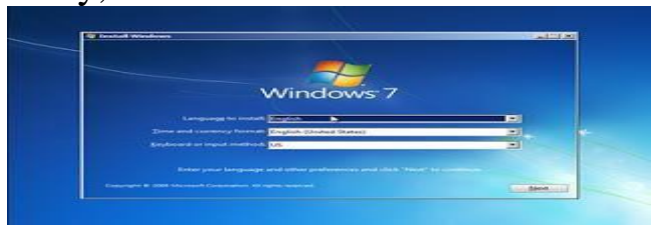

Gambar 13 Memilih Nama Negara

6. Tekan tombol install now 
Jurdimas (Jurnal Pengabdian Kepada Masyarakat)

Vol. I No. 1, Januari 2018, hlm. 34 - 43

Available online at

http://jurnal.stmikroyal.ac.id/index.php/jurdimas

ISSN 2614-7912 (Print)

ISSN 2622-3813 (Online)

10. Di tahap ini kamu bisa melakukan partisi atau membagi Hardisk kedalam beberapa drive, dimana nanti untuk windows 7 berada pada drive (C) dan sisanya drive (D) untuk penyimpanan data kamu nantinya. Atau jika kamu mau partisi setelah instalasi windows 7 langsung saja klik "Next".Biasanya saya langsung klik next, untuk partisinya belakangan.

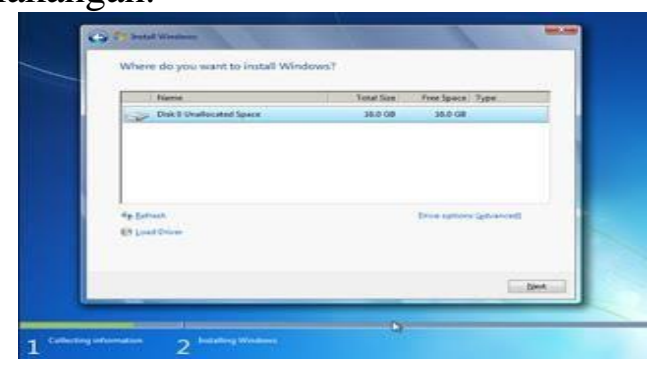

Gambar 18 Memilih Drive yang Akan di gunakan

11. Tunggulah proses ini beberapa saat

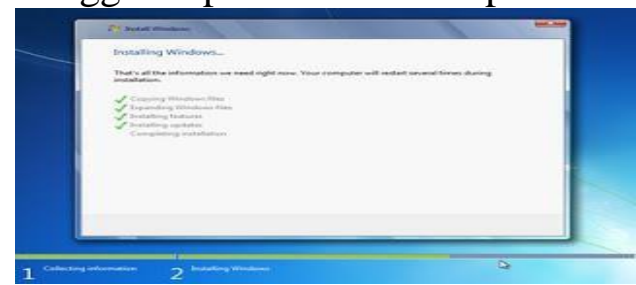

Gambar 19 Proses Penyelesaian

12. Secara otomatis windows akan restart

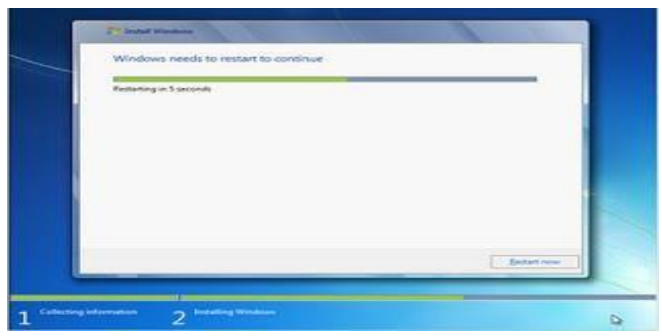

Gambar 20 Proses Restart

13. Setelah restart akan muncul gambar berikut ini

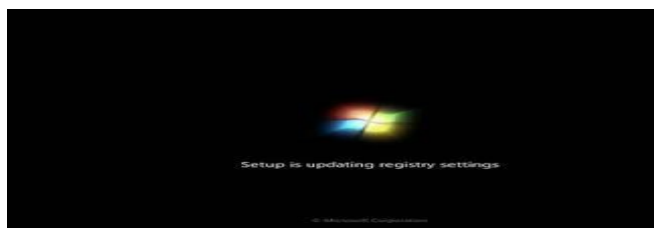

Gambar 21 Setekah Restart 
Jurdimas (Jurnal Pengabdian Kepada Masyarakat)

Vol. I No. 1, Januari 2018, hlm. 34 - 43

Available online at

http://jurnal.stmikroyal.ac.id/index.php/jurdimas

19. Pilihlah level proteksi keamanan dari Microsoft

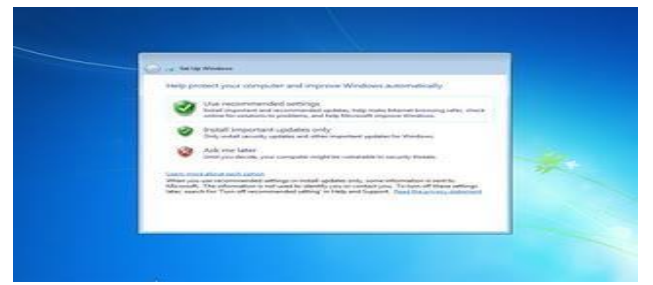

Gambar 27 Pilihan level

20. Atur Zona waktu Anda (untuk Indonesia +7 dari GMT)

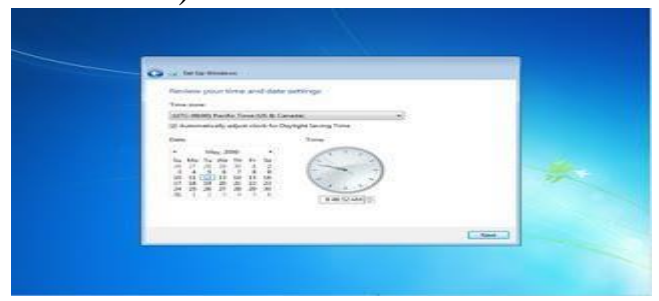

Gambar 28 Atur Zona Waktu

21. Selamat, windows 7 Anda siap digunakan

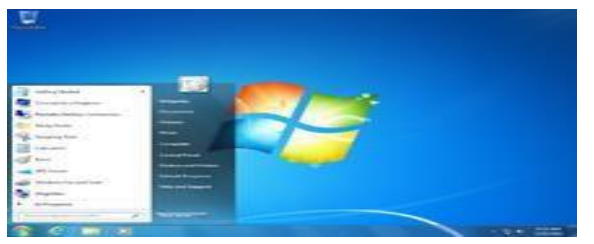

Gambar 29 Tampilan Utama Windows

\section{Instalasi Sistem Operasi Linux (Ubuntu)}

Ubuntu merupakan salah satu distro yang ada pada sistem operasi Linux.Ubuntu merupakan turunan dari distro linux lainnya yaitu debian. Ubuntu saat ini telah mencapai versi 17.04, maksudnya adalah ubuntu versi ini diluncurkan pada tahun 2017 pada bulan 04 (April) dan akan terus muncul versi terbaru berikutnya. Jika ingin membuat Dual OS antara Windows dan Ubuntu, maka sebaiknya buat terlebih dahulu partisi baru untuk menyimpan file sistem Ubuntu.

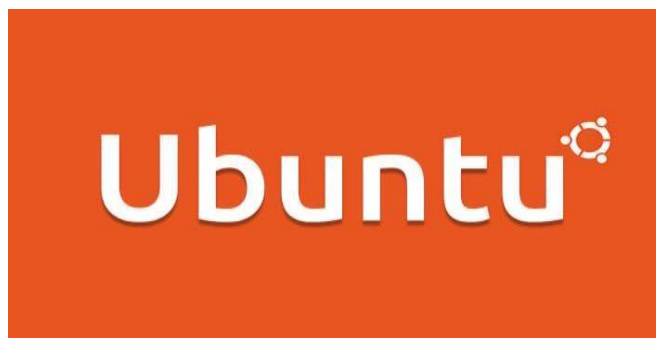

Gambar 30 Tampilan Logo Ubuntu

1. Masukkan CD/DVD master ubuntu 15.04. 2. Pastikan CD/DVD dapat dibaca oleh komputer dengan baik.

3. Restart Komputer.

4. Masuk ke pengaturan BIOS terlebih dahulu. Pilih bada bagian menu BOOT, lalu tempatkan CD/DVD pada posisi booting pertama (paling atas).Kemudian simpan.

5. Biarkan komputer restart otomatis dan tunggu proses selanjutnya.

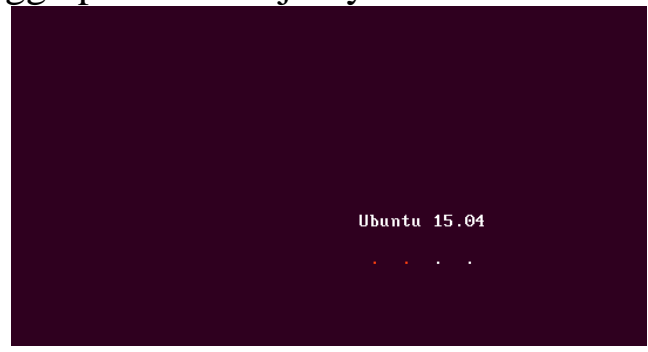

Gambar 31 Tampilan Load Ubuntu

Selanjutnya pilih bahasa yang akan digunakan selama penginstalan nantinya. Disini kami menggunakan bahasa English.Selanjutnya klik Install Ubuntu.

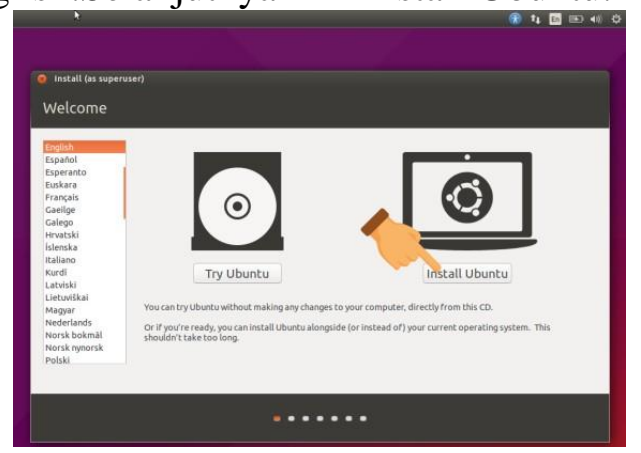

Gambar 32 Tampilan Pemilihan Bahasa Pada tahap ini tidak perlu ada yang dirubah atau dicentang, klik Continue saja untuk melanjutkan. 
Jurdimas (Jurnal Pengabdian Kepada Masyarakat)

Vol. I No. 1, Januari 2018, hlm. 34 - 43

Available online at

http://jurnal.stmikroyal.ac.id/index.php/jurdimas

ISSN 2614-7912 (Print)

ISSN 2622-3813 (Online)

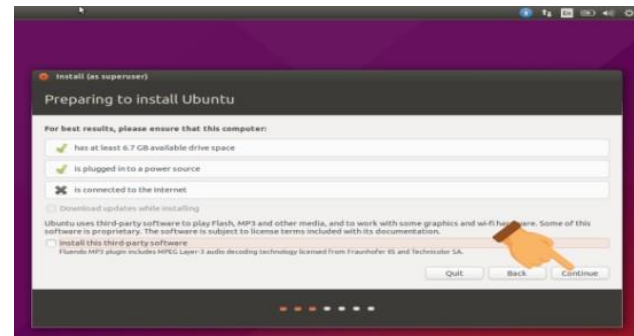

Gambar 33 Proses Instalasi

Pada tahap ini akan ada 2 pilihan opsi. Pilih opsi kedua (Something Else) > Klik Continue.

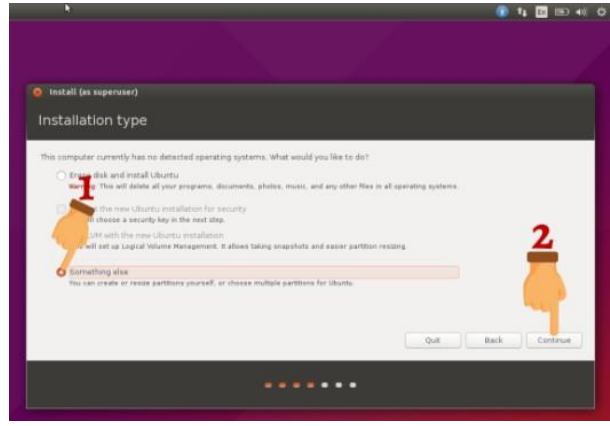

Gambar 34 Memilih Type Instalasi

Selanjutnya kita akan membuat sebuah partisi baru dan mengatur partisi pada hard disk. Klik New Partition Table.

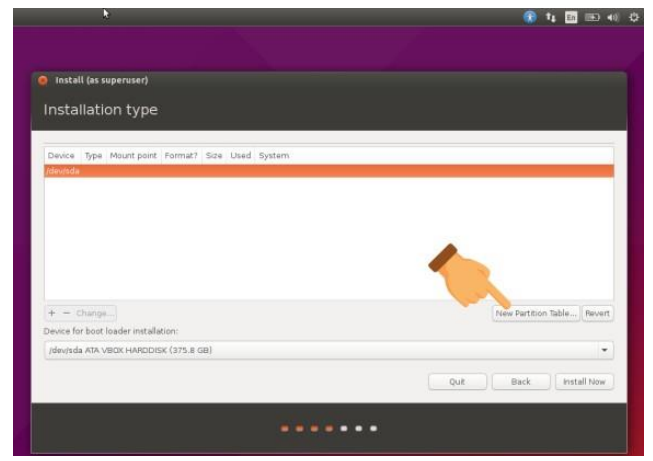

Gambar 35 Memilih Partisi

Klik Continue.

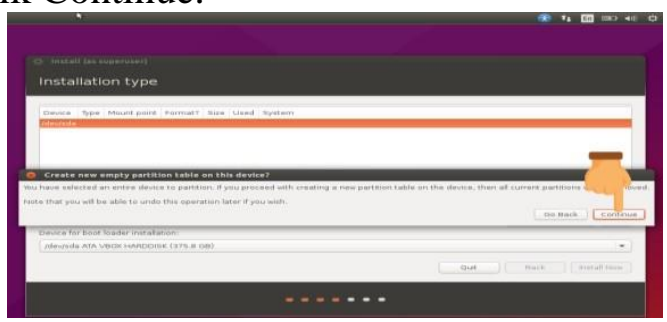

Gambar 36 Memilih Partisi 
Jurdimas (Jurnal Pengabdian Kepada Masyarakat)

Vol. I No. 1, Januari 2018, hlm. 34 - 43

Available online at

http://jurnal.stmikroyal.ac.id/index.php/jurdimas

ISSN 2614-7912 (Print)

ISSN 2622-3813 (Online)

Tentukan kapasitas pada partisi ini. Lalu pilih Logical $\gg$ Beginning of this space. Pada kotak Use as pilih Swap area. Bagi saya partisi swap area ini merupakan partisi yang penting (wajib). Swap area merupakan sebuah partisi yang nantinya akan menjadi Memory Virtual dengan menggunakan hard disk sebagai medianya. Lalu klik OK.

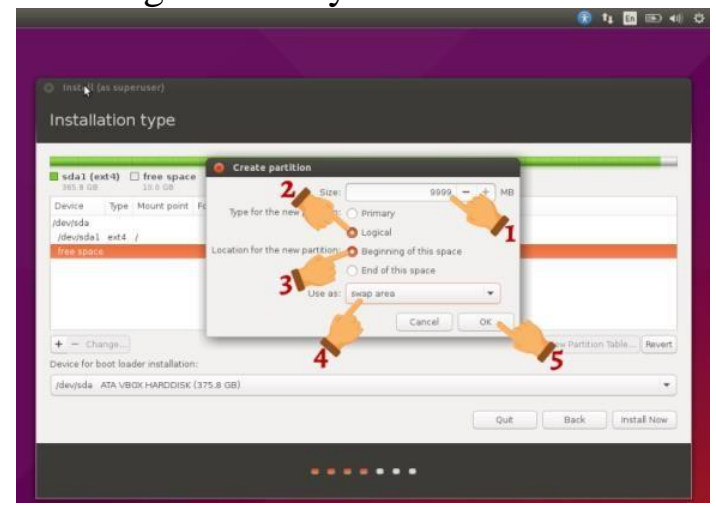

Gambar 39 Memilih Area

Maka hasilnya akan terlihat seperti pada gambar di bawah. Kita telah selesai membuat 2 buah partisi, yaitu / dan swap area.

Selanjutnya klik Install Now.

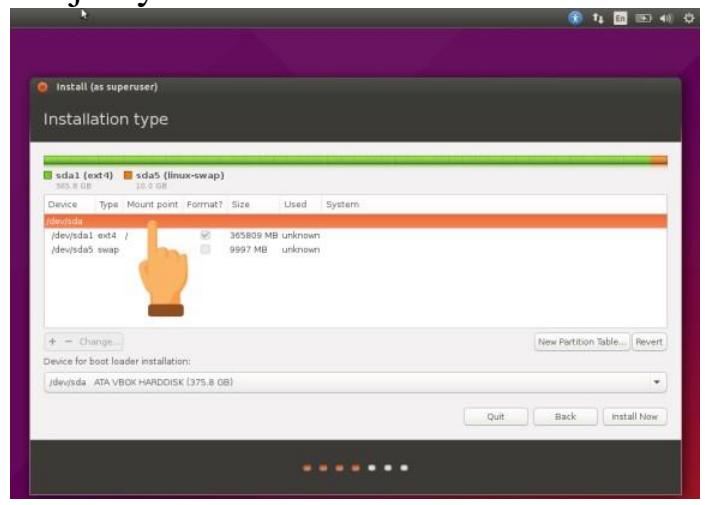

Gambar 40 Membuat 2 Buah Partisi

Klik Continue.

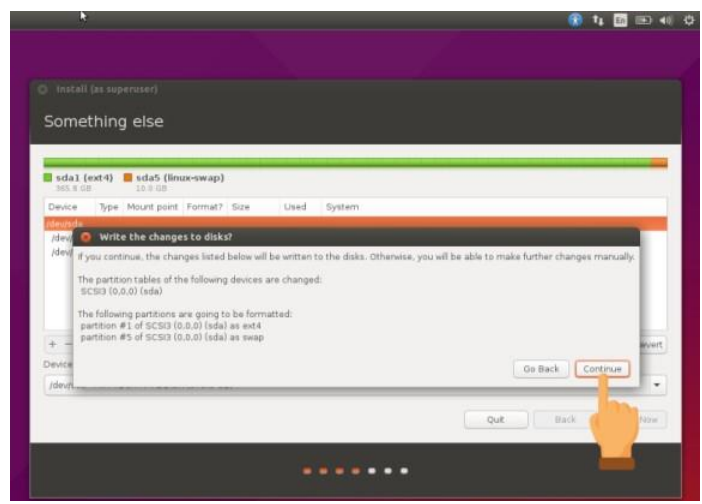

Gambar 41 Clik Continue

Pilih zona waktu negara anda (Jakarta, Indonesia) >> Klik Continue.

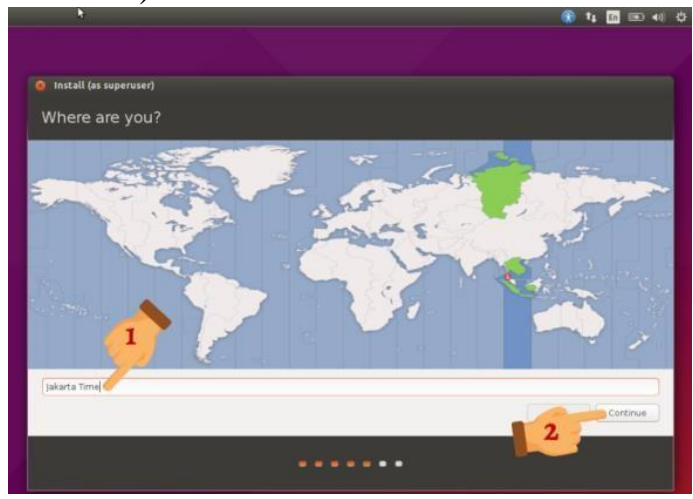

Gambar 42 Memilih Lokasi Negara

Selanjutnya pilih bahasa inputan keyboard atau biarkan mengikuti default saja.Kami menggunakan English (US).

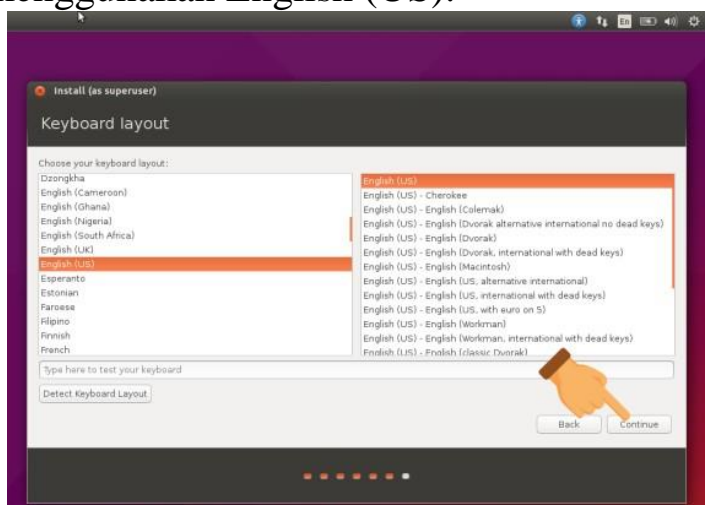

Gambar 43 Memilih Inputan Keyboard

Selanjutnya yaitu Anda disuruh untuk mengisikan data untuk user secara lengkap.Isikan dengan data yang benar dan gampang di ingat passwordnya.Setelah selesai klik Continue. 


\section{Jurdimas (Jurnal Pengabdian Kepada Masyarakat)}

Vol. I No. 1, Januari 2018, hlm. 34 - 43

Available online at

http://jurnal.stmikroyal.ac.id/index.php/jurdimas

ISSN 2614-7912 (Print)

ISSN 2622-3813 (Online)

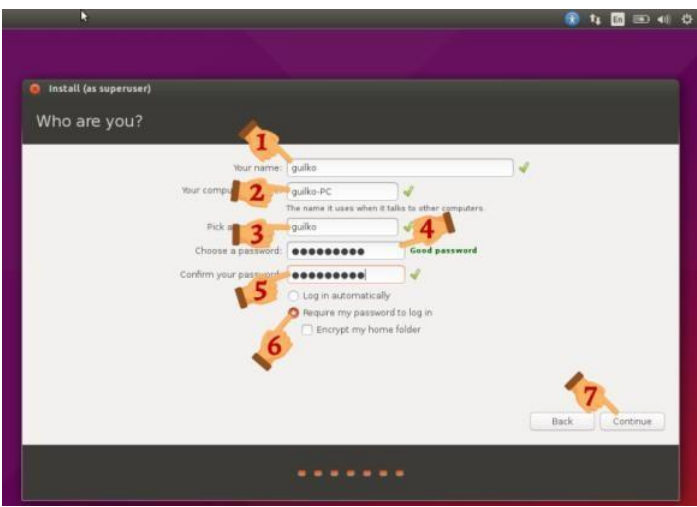

Gambar 44 Memasukkan User dan Password

Proses penginstalan dan penyalinan data sistem operasi dimulai. Tunggu proses ini sampai selesai. Biasanya waktu yang dibutuhkan pada tahap ini sekitar 10-20 menit.

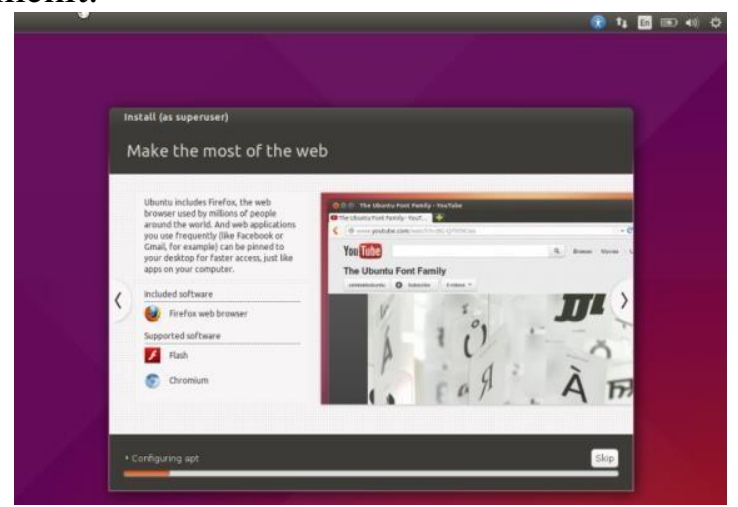

Gambar 45 Copy File

Setelah proses penginstalan selesai, maka akan ada perintah seperti pada tampilan di bawah. Klik Restart Now.

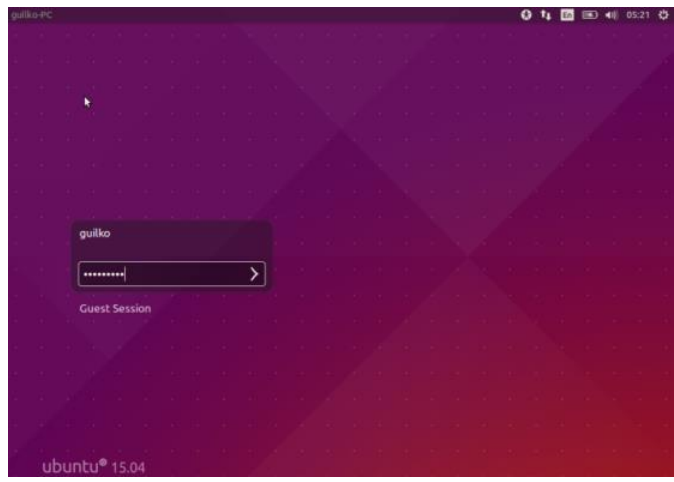

Gambar 46 Masukkan Password Proses penginstalan telah selesai.

\section{Instalasi Aplikasi}

\subsection{Instalasi VLC}

VLC Merupakan program aplikasi multimedia, double klik setup.exe

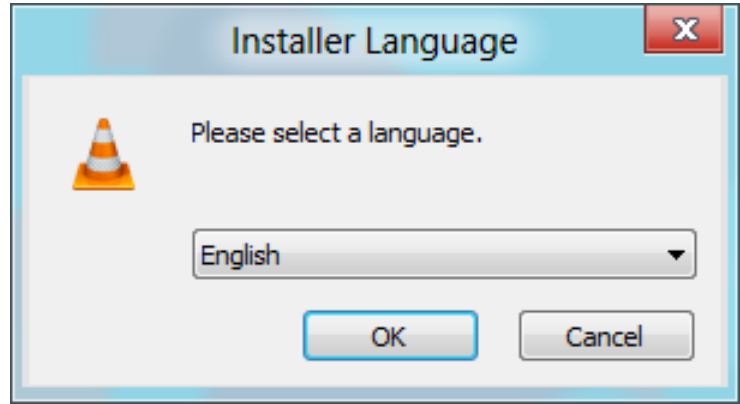

Gambar 47 Memilih Bahasa

\section{2. layar Selamat Datang}

VLC dimulai dengan selamat datang.lalu klikNEXT.

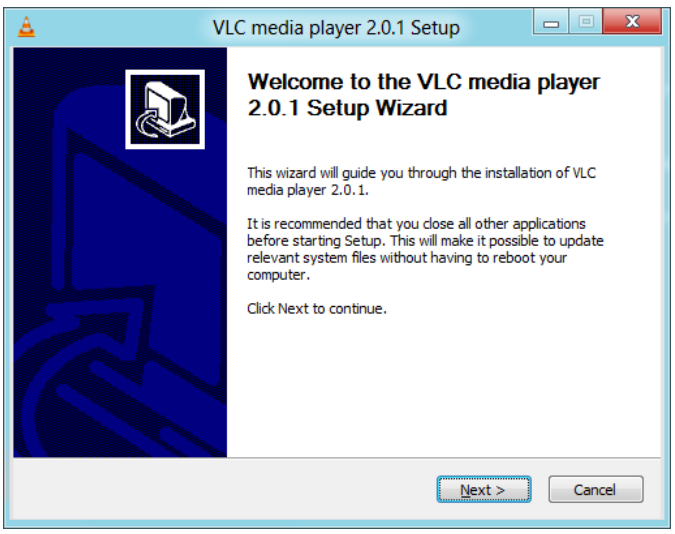

Gambar 48 Klik Next

\section{Perjanjian Lisensi}

Perjanjian lisensi klik sajaNEXT.

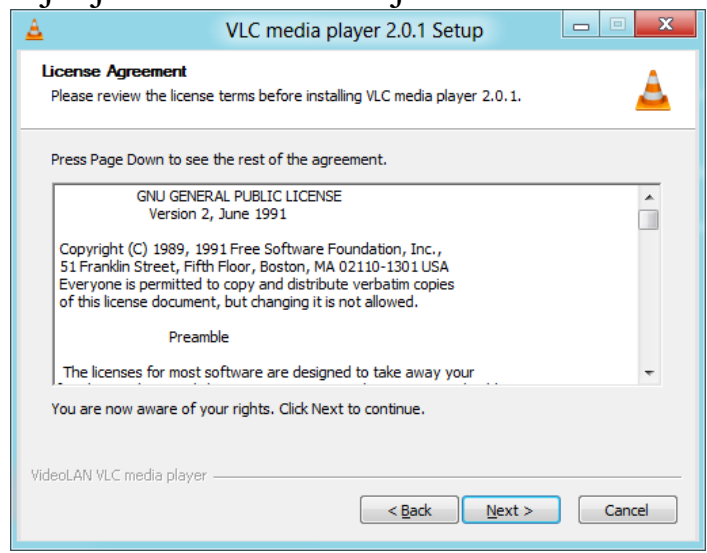

Gambar 49 Perjanjian Lisensi 
Jurdimas (Jurnal Pengabdian Kepada Masyarakat)

Vol. I No. 1, Januari 2018, hlm. 34 - 43

Available online at

ISSN 2614-7912 (Print)

http://jurnal.stmikroyal.ac.id/index.php/jurdimas

ISSN 2622-3813 (Online)

4. Pilih Komponen

Menu ini menyediakan Anda dengan kemampuan untuk menyesuaikan instalasi Anda.

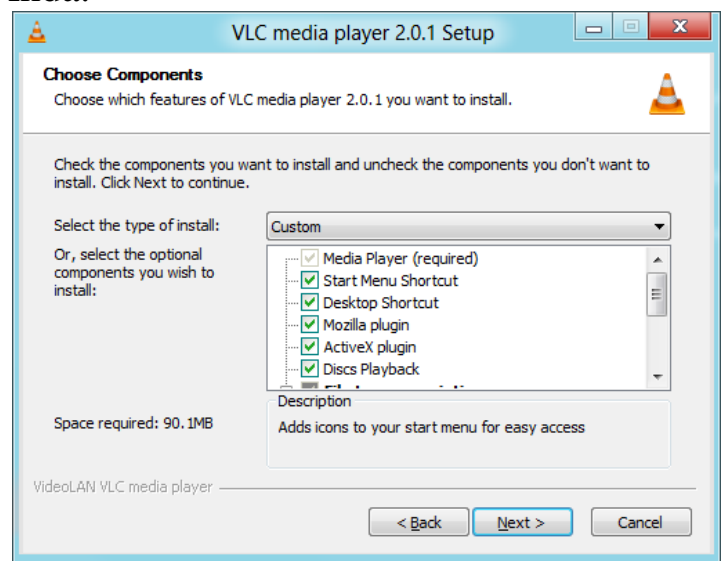

Gambar 50 Memilih Komponen

5. Pilih lokasi

Anda memilih folder instalasi dengan Browse ..., lalu klik INSTALL..

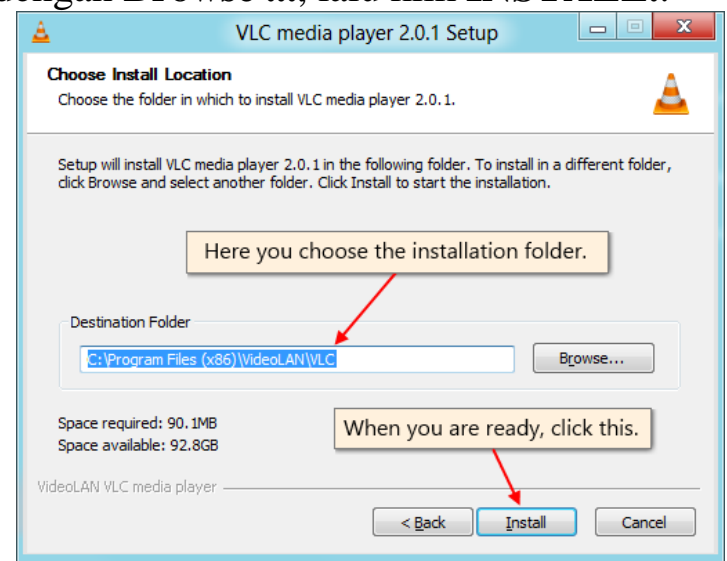

Gambar 51 Memilih Lokasi

5. Sekarang menginstal

Tunggu sampai proses menginstal.

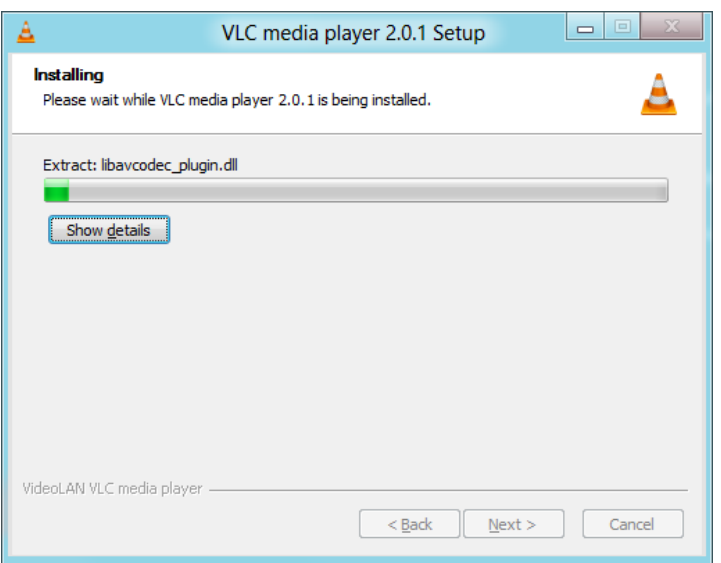

Gambar 52 Proses

7. Instalasi lengkap

Setelah instalasi selesai, Anda dapat Menjalankan VLC.FINISH

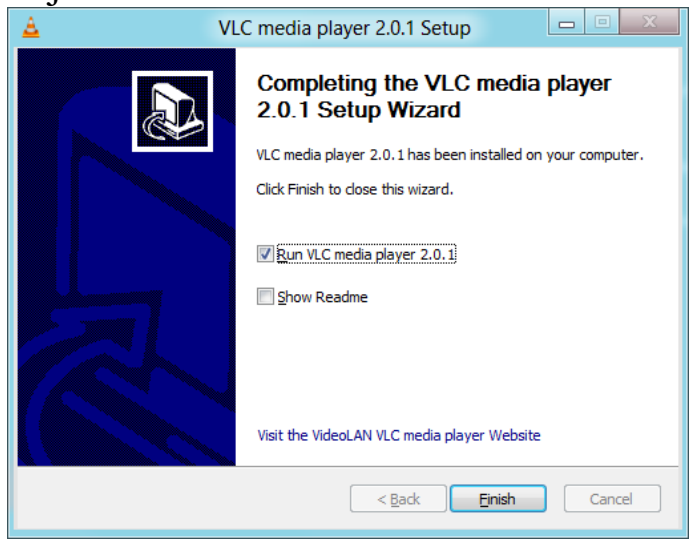

Gambar 53 Selesai

\subsection{Instalasi Winrar}

1. WinRAR.exe Klik 2x.Kemudian Klik Install tombol di bagian bawah.

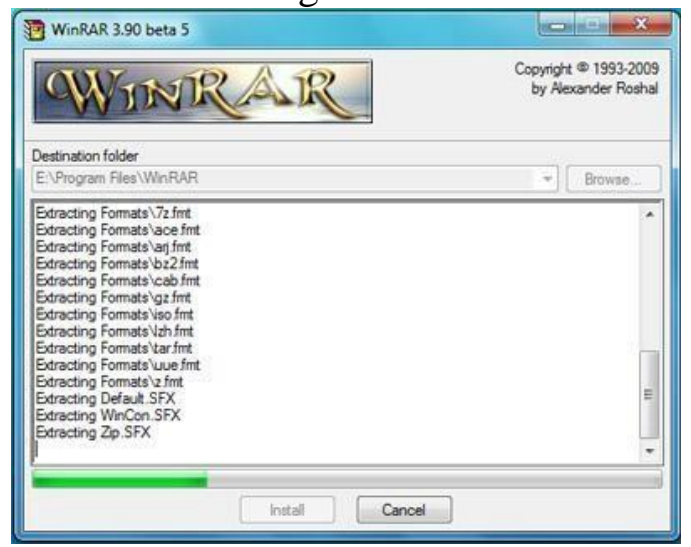

Gambar 54 Proses Instal 


\section{Jurdimas (Jurnal Pengabdian Kepada Masyarakat)}

Vol. I No. 1, Januari 2018, hlm. 34 - 43

Available online at

http://jurnal.stmikroyal.ac.id/index.php/jurdimas

2. Pilih format yang Anda ingin. Centang semua Kemudian Klik "OK"

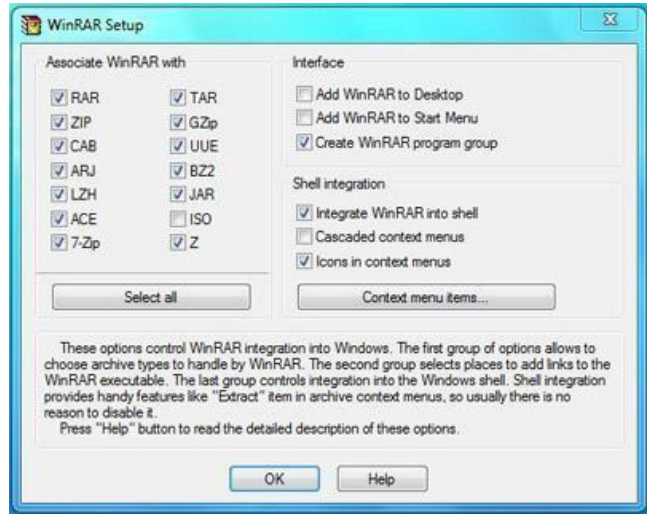

Gambar 55 Memilih Jenis File

3. Dalam dialog ini Anda memiliki lima pilihan, jika Anda ingin menjalankan winrar, klik Jalankan WinRAR tombol. Lalu klik "Done"

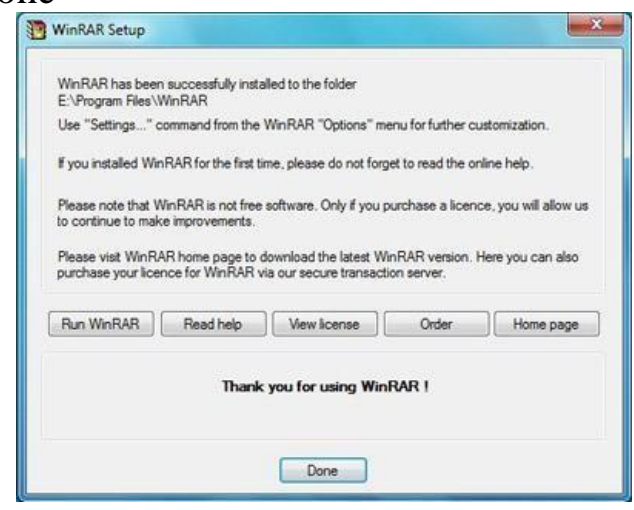

Gambar 56 Selesai

\section{SIMPULAN}

Kesimpulan dari kegiatan pengabdian kepada masyarakat di SMA Swadaya Tinggi Raja ini adalah :

1. Merakit komputer dan mengenal komponen komputer merupakan suatu kebutuhan untuk mengenal dasar dan sebagai penegetahuan dalam IPTEK.

\section{DAFTAR PUSTAKA}

MediaCom. "Belajar Mudah Merakit Komputer", Yogyakarta, Raya Fahreza,

Kunci Aksara. "Merakit Komputer Semudah Membalikan Telapak Tangan (2014)", Yogyakarta, $\quad$ Allawi Duratun Fatwa 